\title{
The Paradox of Safe Areas in Ethnic Civil Wars
}

\author{
Stefano Recchia \\ University of Cambridge, U.K. \\ sr638@cam.ac.uk
}

\begin{abstract}
Safe areas established by powerful states can improve short-term civilian protection during ethnic civil wars. Paradoxically, however, they may worsen the plight of vulnerable civilians over the medium term. This can occur in three ways. First, when safe areas encompass sizeable territories within a broader conflict zone, they may reduce incentives for protected groups to compromise during peace negotiations, thus prolonging hostilities. Second, there is a nontrivial possibility that protected groups will use the safe areas as a base for launching high-risk offensives, deliberately putting civilians at risk in the hope of drawing the protection forces more deeply into the war. Third, safe areas may embolden protected groups to seek unilateral secession, further increasing the risk of conflict escalation. By elucidating the causal mechanisms involved, this article helps us assess the probability of these outcomes occurring. States that consider intervening militarily to establish safe areas in ethnic civil wars need to weigh the short-term benefits against these possible longer-term downsides.
\end{abstract}

\section{Keywords}

civilian protection - humanitarian intervention - safe zones - safe havens - moral hazard - secessionism

* For helpful comments on previous versions of this paper, I would like to thank workshop participants at the Research Center on Governance in Areas of Limited Statehood, Free University Berlin; the Department of Political Science, Duke University; the School of International Service, American University; and the Department of Politics and International Relations, Oxford University. I am especially grateful to Boaz Atzili, Kyle Beardsley, Susanna Campbell, Janina Dill, Peter Feaver, Joe Grieco, Daniel Jacob, Bernd Ladwig, Leah Owen, Aaron Rapport, Andrea Ruggeri, and Jordan Tama for their thoughtful feedback, and to Jenny Yang for excellent research assistance. Open access publication was made possible by an EC Career Integration Grant.

(C) RECCHIA, 2018 | DOI 10.1163/1875984X-01003006

This is an open access article distributed under the terms of the prevailing CC-BY-NC-ND License at the time of publication. 
Safe areas are central to current debates about civilian protection in civil war situations. Since the 2011 Arab Spring uprisings, there have been persistent calls for powerful states to establish safe areas in Middle Eastern countries torn apart by ethno-sectarian violence-notably, Syria, Libya and Iraq. With respect to Syria, editorials and opinion pieces in Western newspapers have called on the United States and NATO to lead international forces protecting mainly Sunni and Kurdish areas' until a political settlement can be reached. ${ }^{1}$ Concerning Libya, already in 2011, the Arab League called on powerful states acting through the United Nations Security Council (UNSC) to 'establish safe areas in places exposed to shelling.' ${ }^{2}$ Regarding Iraq, pundits and human rights activists have urged the United States and its allies to establish safe areas for Christian and Turkmen minorities. ${ }^{3}$ There have also recently been calls to set up safe areas in other conflict zones, such as in Rakhine State in Myanmar to protect vulnerable Rohingya civilians. ${ }^{4}$

Internationally proclaimed safe areas where vulnerable populations can find shelter from violent conflict without having to leave their own state seemingly offer an appealing, relatively low-cost means of civilian protection during civil wars. More coercive types of humanitarian intervention aimed at forcing local parties to accept a political solution have been criticised on grounds that they violate state sovereignty, are likely to result in protracted international occupations, and temporarily upset the local balance of power in ways that make genuinely self-sustaining peace settlements more difficult. ${ }^{5}$ By contrast,

1 'Syria: What Next?', The Economist, 15 April 2017. See also Thomas L. Friedman, 'President Trump's Real-World Syria Lesson', New York Times, 5 April 2017; Nicholas Burns and James Caffrey, 'The Diplomatic Case for America to Create a Safe Zone in Syria', Washington Post, 4 February 2016; and Kori Schake, 'Safe Zones Proved Their Value after the Gulf War', New York Times, 19 July 2016.

2 'Outcome of the Extraordinary Meeting of the Arab League on the Implications of Current Events in Libya', 12 March 2011, http://responsibilitytoprotect.org/index.php/document -archive/government, accessed 12 January 2018. Subsequently, in 2015, European and North African countries reportedly held serious discussions about setting up 'a safe zone in eastern Libya that would extend from the Mediterranean coast ... to the border with Niger'. See ввС Monitoring Middle East, 'Algeria, Tunisia "Rejected Western proposal for safe zone" in Libya in 2015', 11 June 2016.

3 See, for instance, Dominique Soguel, 'A Sanctuary for Iraqi Yazidis', Christian Science Monitor, 12 August 2014; and Andrew Doran, Robert Nicholson, Stephen Hollingshead, and Robert Destro, 'Safe Zone: Security in the Aftermath of IsIs', The American Interest, 2 March 2017.

4 Serajul Quadir, Ruma Paul, and Krishna N. Das, 'Bangladesh Wants "Safe Zones” to Ease Rohingya Crisis', Reuters, 8 September 2017.

5 Some of the most influential writings in this vein are Mohammed Ayoob, 'Humanitarian Intervention and State Sovereignty', International Journal of Human Rights, 6/1: 81-102 (2002); 
the argument goes, when powerful states intervene with the narrower goal of establishing safe areas, they can discharge their responsibility to protect vulnerable civilians by relying primarily on deterrence and defence rather than coercion. Because safe areas involve only limited interference in domestic politics, local parties are left to resolve their differences largely on their own, which increases the prospects that any peace settlement that is achieved will hold. Finally, safe areas set up in war-torn countries can help reduce international refugee flows, thereby offering further pragmatic appeal to rich-world politicians faced with domestic political backlash against incoming refugees. ${ }^{6}$

Safe areas established by powerful states with robust military capabilities can undoubtedly improve civilian protection in civil war situations, at least in the short term. However, internationally proclaimed safe areas, set up without the consent of one or several local parties to the conflict (that is, "nonconsensually'), are in fact fairly intrusive. Establishing such areas may require that intervening powers initially adopt a strategy of military coercion, or 'compellence', until the immediate threat to the population is withdrawn. Only once this is achieved can the interveners shift to a deterrence strategy (involving the threat of punishing military action in response to violations of the area), to be complemented by defensive operations as necessary (aimed at repelling hostile incursions should they occur). ${ }^{7}$

Either way, the deployment of robust international military forces to establish and enforce safe areas in civil wars, like other forms of military intervention, can be expected to shift the balance of power on the ground and with it the incentives facing local political actors-especially when safe areas encompass sizeable territories within a broader conflict zone. After such safe areas have been established, the leaders of protected groups are likely to become

Alan J. Kuperman, 'The Moral Hazard of Humanitarian Intervention: Lessons from the Balkans', International Studies Quarterly, 52/1: 49-80 (2008); Richard K. Betts, 'The Delusion of Impartial Intervention', Foreign Affairs, 73/6: 20-33 (1994); and Kyle Beardsley, The Mediation Dilemma (Ithaca, NY: Cornell University Press, 2011).

6 See, for example, Burns and Caffrey, 'The Diplomatic Case for a Safe Zone in Syria'; Doran et al., 'Safe Zone: Security in the Aftermath of IsIs'; and Lokman Çetinkaya, Safe Zone: A Response to Large-Scale Refugee Outflows and Human Suffering (New York: Springer, 2017).

7 For helpful discussions of safe areas from a military operations perspective, see Barry Posen, 'Military Responses to Refugee Disasters', International Security, 21/1: 93-105 (1996); Taylor Seybolt, Humanitarian Military Intervention: The Conditions for Success and Failure (New York: Oxford University Press, 2007), pp. 187-9o; and Sarah Sewall, 'Military Options for Preventing Atrocity Crimes' in Serena Sharma and Jennifer Welsh (eds.), The Responsibility to Prevent: Overcoming the Challenges of Atrocity Prevention (New York: Oxford University Press, 2016), pp. 168-77. 
more risk acceptant. This, I argue, may paradoxically undermine civilian protection over the medium term.

Non-consensual, sizeable safe areas established by powerful states in situations of ethnic civil war can produce adverse outcomes in three ways. First, they may reduce incentives for the leaders of protected groups to compromise during negotiations, thereby making consensual peace agreements more difficult and potentially prolonging hostilities. Second, there is a nontrivial possibility that protected groups will use the safe areas as a base for launching high-risk offensives, deliberately putting civilian lives at risk in the hope of drawing the protection forces more deeply into the war. Third, protected groups may be emboldened to seek unilateral secession, increasing the risk of conflict escalation and thus further jeopardising civilian security. These dynamics can interact in complex ways; nevertheless, I discuss them separately, simplifying somewhat in order to illustrate and analyse underlying mechanisms.

This article focuses on safe areas that: (a) are established in situations of ethnic civil war, where opposing groups tend to be fairly cohesive and deeply mutually hostile; (b) are proclaimed against the will of one or several local parties to the conflict; (c) are set up and policed by powerful external actors, such as the United States and its most militarily capable allies; and (d) encompass sizeable territories, such as major cities, districts, and entire regions. For the purpose of the article, I define 'safe areas' as designated portions of a state's territory, involving the deployment of external military forces, with the primary purpose of offering protection to threatened civilian populations in situations of violent conflict. ${ }^{8}$ I use the terms 'safe area', 'safe zone', and 'safe haven' interchangeably. When discussing ethnic civil wars, I use the term 'ethnic' as shorthand for ethno-linguistic, tribal, and religious. ${ }^{9}$

There have been only four instances of large safe areas established by powerful states in situations of ethnic civil war, all of them over the last quarter century: the Kurdish safe enclave set up by the United States and its allies in northern Iraq in 1991; the Bosnian safe areas that were formally proclaimed by the UNSC in 1993 and had NATO theoretically committed to their protection; the zone humanitaire sûre established by France in Rwanda in 1994 towards the end of the civil war there; and finally, the de facto safe zone encompassing all of Kosovo that was established by NATO after the 1999 air campaign against

8 Similar definitions can be found in Phil Orchard, 'Revisiting Humanitarian Safe Areas for Civilian Protection', Global Governance, 20/1:55-75 (2014), p. 55; and Çetinkaya, Safe Zone, p. 1.

9 For a justification of this approach, see Kanchan Chandra, 'Ethnic Parties and Democratic Stability', Perspectives on Politics, 3/2: 235-52 (2005). 
Serbia. ${ }^{10}$ The Rwandan safe zone was set up very late during the civil war, when the capital, Kigali, was about to fall and the underlying power struggle was thus all but resolved; it had only a modest impact in terms of civilian protection, and it was terminated after less than two months. Therefore, it is of only limited interest for the purpose of this article, and I will not discuss it further. ${ }^{11}$ By contrast, the safe areas established in northern Iraq, Bosnia, and Kosovo all aimed to offer longer-term protection through a combination of ground troops and air power, while the broader political dispute remained unresolved. These safe areas all made important contributions to civilian protection in the short term; yet at the same time, to varying degrees, they had problematic implications over the medium term.

This article is not a call for general pessimism about safe areas. Instead, by elucidating the mechanisms through which safe areas established by powerful states can produce adverse outcomes in terms of civilian protection over the medium term, the article helps us assess the probability of these outcomes occurring. It thereby facilitates consequentialist moral reasoning, which rests on evaluating the likely consequences of various courses of action, and it may contribute to more informed policymaking. Ultimately, national decision-makers in the United States and elsewhere who consider deploying their country's military assets to establish safe areas during ethnic civil wars need to carefully weigh the short-term benefits against possible longer-term downsides. As long as the benefits are expected to be substantial, safe areas can be a worthwhile policy option. Nevertheless, we need to be aware of the risks.

Sometimes, I will conclude, especially when powerful states are unwilling to shoulder potentially long-term commitments and a fortiori when the local parties clamouring for protection have previously manifested secessionist tendencies, military intervention to establish and enforce extensive safe areas may be unwise. Alternative policy options should then be explored. Powerful states could offer logistical and financial support to UN peacekeepers who are already deployed in civilian protection missions to establish smaller safe areas that are unlikely to affect local conflict dynamics (for example, around

10 On Kosovo as a de facto safe area, see Seybolt, Humanitarian Military Intervention, pp. $215^{-18}$.

11 For useful discussions of the Rwandan safe zone, see Gérard Prunier, 'Operation Turquoise: A Humanitarian Escape' in Howard Adelman (ed.), The Path of a Genocide: The Rwanda Crisis from Uganda to Zaire (New Brunswick, NJ: Transaction Publishers, 2000); Carol McQueen, Humanitarian Intervention and Safety Zones: Iraq, Bosnia and Rwanda (London: Palgrave Macmillan, 2005), pp. 123-48; and Nicholas Wheeler, Saving Strangers: Humanitarian Intervention in International Society (Oxford: Oxford University Press, 2000), pp. 231-37. 
displaced person camps). Another option would be for powerful states to use their good offices in an effort to persuade the local parties themselves to set up consensual safe areas, or 'neutral zones' (perhaps on the basis of reciprocity, when each side has vulnerable populations), and subsequently to help deploy UN peacekeepers to monitor compliance.

The rest of the article is structured as follows: The next section briefly introduces the notion of rights-based consequentialism, which constitutes the moral foundation for my analysis. Thereafter, I briefly trace the historical evolution of safe areas: I discuss in particular the experiences in Bosnia and northern Iraq during the 1990s, given how central these cases are to current debates. Following on from that, I examine the potential problematic consequences of safe areas in greater detail and identify related causal mechanisms. I develop my argument through a combination of deductive reasoning, historical process tracing, and counterfactual analysis. The conclusion calls for a morally informed cost-benefit assessment.

\section{Safe Areas and Rights-Based Consequentialism}

Consequentialism, as the term suggests, is an ethical theory which holds that our moral assessment of an activity should be based primarily on whether it produces good consequences, or outcomes. The best-known form of consequentialism is utilitarianism, which identifies the 'good' as utility (defined as aggregate welfare or happiness). Utilitarianism is usually viewed as incompatible with individual rights-based moral arguments. But there are non-utilitarian forms of consequentialism that allow us to posit other values, such as human rights, as the intrinsically good state of affairs. As Amartya Sen notes, 'although a rights-based moral theory cannot coexist with "welfarism" [that is, traditional utilitarianism], it can very well do so with [other forms of] consequentialism. ${ }^{12}$ Rights-based consequentialism, which Sen pioneered, holds that in our moral evaluation of a particular activity, we should proceed by 'incorporating the value of right fulfilment and the disvalue of right violation in the assessment of resulting states of affairs.' ${ }^{13}$

This article focuses on the consequences of safe areas established by powerful states in terms of physical integrity rights. The purpose of safe areas is to protect civilians from bodily harm; therefore, it seems appropriate

\footnotetext{
12 Amartya Sen, On Ethics and Economics (New York: Blackwell, 1987), p. 75.

13 Ibid., p. 73. For a useful discussion see also William J. Talbott, 'Consequentialism and Human Rights', Philosophy Compass, 8/11: 1030-40 (2013).
} 
to evaluate them first and foremost against their ability to actually improve people's enjoyment of these most basic human rights, not only in terms of stopping immediate rights violations but also in terms of lowering (or at least not increasing) the chances of large-scale rights violations in the future. I thus agree with James Pattison that we should judge humanitarian interventions, including those aimed at establishing and enforcing safe areas, by whether they effectively 'increase enjoyment of human rights in the long term, compared to other potential courses of action - the counterfactual.' ${ }^{14}$

The relevant baseline for comparison is a hypothetical alternative world in which outside powers stopped short of proclaiming and enforcing large safe areas and instead sought, for instance, to facilitate pragmatic agreements among the warring parties by applying diplomatic pressure and offering various inducements. Although such counterfactual reasoning is inherently difficult, scholars increasingly recognise that carefully constructed counterfactuals can help us to 'probe the causes and contingency of the world we know' and 'are an indispensable means of evaluating it, empirically and normatively'. ${ }^{15}$

\section{Effective Protection through Muscular Deterrence?}

The current understanding of safe areas as requiring robust enforcement by outside actors is relatively new, emerging only during the 1990s. Before that, safe areas used to be more modest undertakings: they were typically established through negotiations among the conflicting parties, were limited to specific buildings and their immediate surroundings (for instance, hospital zones or religious complexes), were more or less fully demilitarised, and relied on the parties' voluntary compliance. During the second half of the twentieth century, such limited safe areas were set up on a few occasions pursuant to the 1949 Geneva Conventions on the protection of civilians in war, such as during the 1971 Bangladesh War and the later phases of the Vietnam War. These safe areas were usually monitored by neutral observers from the International Committee of the Red Cross, without any international military deployment. These early safe areas were also entirely apolitical, reflecting the traditional

14 James Pattison, Humanitarian Intervention and the Responsibility to Protect (New York: Oxford University Press, 2011), pp. 74, 81. See also Seybolt, Humanitarian Military Intervention, Ch. 2.

15 Richard Ned Lebow, Forbidden Fruit: Counterfactuals and International Relations (Princeton, NJ: Princeton University Press, 2010), pp. 6, 17. See also Philip Tetlock and Aaron Belkin (eds.), Counterfactual Thought Experiments in World Politics (Princeton, NJ: Princeton University Press, 1996). 
understanding of humanitarianism as a neutral and impartial approach to relieving human suffering. ${ }^{16}$

Toward the end of the twentieth century, however, the international community's attention was drawn to a seemingly new type of ethno-sectarian conflict: in regions as disparate as the Balkans, the Caucasus, and the African Great Lakes region, civilians were no longer mere bystanders to the violence but were instead increasingly targeted because of their membership in particular groups. In light of these perceived changes in the character of war, many in the humanitarian community concluded that traditional safe areas based on consent and voluntary compliance by the conflicting parties were no longer adequate. Nevertheless, the awareness that robust enforcement by powerful outside actors might be desirable emerged only slowly - in large part as a result of the experience in the former Yugoslavia, especially Bosnia.

\section{Bosnia}

The Bosnian War was a three-way ethnic conflict between Bosnian Muslims, Croats, and Serbs. In the late spring of 1993, roughly one year into the war, the UNSC designated six Bosnian towns with majority Muslim populationsSrebrenica, Tuzla, Zepa, Gorazde, and Bihac, as well as the capital, Sarajevoas 'safe areas'. The goal was to prevent the militarily stronger Bosnian Serb faction from taking control of these besieged Muslim enclaves.

Srebrenica was initially declared a demilitarised zone in March 1993, loosely following the Geneva Conventions, on the basis of a UN-mediated agreement among the local parties. ${ }^{17}$ As a UN document from this period pointed out, 'the demilitarisation of Srebrenica was a step agreed by the parties ... [Consequently,] the onus remains on the parties to treat Srebrenica as a "safe area". ${ }^{18}$ Over the next several weeks, however, the United States and its European allies moved away from this consent-based model, and the remaining safe areas were proclaimed over Serb objections. (UNSC Resolution 824, adopted in May 1993, simply demanded that all the aforementioned towns be treated as safe

16 See Karin Landgren, 'Safety Zones and International Protection: A Dark Grey Area', International Journal of Refugee Law, 7/3: 438-40 (1995); and McQueen, Humanitarian Intervention and Safety Zones, pp. 3-6.

17 The Serbs seemingly consented to this primarily to prevent UN peacekeepers, who had entered Srebrenica while escorting humanitarian convoys but then considered the possibility of staying put to protect the town's population, from establishing a protected safe area de facto. See McQueen, Humanitarian Intervention and Safety Zones, pp. 58-64.

18 Kofi Annan, 'Srebrenica', diplomatic cable, un Department for Peacekeeping Operations to UNProfor Zagreb (Doc. No. MSC 676), 23 April 1993. 
areas). This in spite of the fact that the Western powers had no clear position on how, or indeed whether, to defend the areas in case of attack.

Security Council Resolution 836, adopted in June, mandated Un peacekeepers 'to deter attacks against the safe areas' and authorised 'member states, acting nationally or through regional organisations ... to take all necessary measures, through the use of air power ... in reply to bombardments against the safe areas'. Yet us President Bill Clinton, under pressure from a risk-averse Pentagon, declined to deploy American ground troops to actually defend the safe areas. Instead, the Americans insisted on aerial deterrence through NATO.$^{19}$ The western Europeans, for their part-primarily Britain, France, and the Netherlands - contributed additional troops to the UN protection force in Bosnia (UNPROFOR); but these troops were constrained by highly restrictive rules of engagement and thus offered little more than a symbolic deterrent. The Europeans remained hesitant to countenance NATO air strikes, fearing an escalation, even after the safe areas came under attack from Serb forces. ${ }^{20}$ Consequently, NATO did not launch its first limited air strikes until the spring of 1994, and for a full year thereafter, the alliance's military action amounted to 'really just the odd bomb here and there', as Robert Hunter, the us ambassador to NATO at the time, recalls. ${ }^{21}$

The expectation, or hope, was that the mere presence of UN troops and the threat of air strikes would deter attacks against the safe areas. But by the end of 1994, the Bosnian Serbs had exposed the West's deterrent threat as a bluff, and UN forces were essentially impotent in the face of intensifying Serb shelling of the Bihac safe area. Although NATO at first launched limited air strikes against Serb positions in early November, it swiftly suspended these after the Serbs took about $250 \mathrm{UN}$ peacekeepers hostage and European governments insisted that NATO should desist from further action. Policymakers in Washington, still determined to limit us liability, privately concluded in late November 1994 that, for the time being, 'the "stick" of military pressure seems no longer viable. ${ }^{22}$ After this, there were no further NATO air strikes for several

19 For a discussion of how us policy on Bosnia was influenced by civil-military relations, see Stefano Recchia, Reassuring the Reluctant Warriors: us Civil-Military Relations and Multilateral Intervention (Ithaca, NY: Cornell University Press, 2015), Ch. 4.

20 See Steven Burg and Paul Shoup, The War in Bosnia-Herzegovina: Ethnic Conflict and International Intervention (Armonk, NY: M.E. Sharpe, 2000), pp. 264-68.

21 Author interview with Robert Hunter, us Permanent Representative to NATO, 1993-97 (Arlington, vA, 11 March 2010). For details of the air strikes, see United Nations General Assembly (UNGA), 'Report of the Secretary-General on the fall of Srebrenica', A/54/549, 15 November 1999, p. 34.

22 Antony Lake, 'Bosnia Policy after the Fall of Bihac', memorandum for the president, 27 November 1994, https://www.cia.gov/library/readingroom/docs/1994-11-27B.pdf, accessed 
months. It was not until the summer of 1995, after the Bosnian Serbs, possibly emboldened by the hesitant nature of Western policy, overran Srebrenica and killed virtually its entire male population, that the Americans and Europeans were finally shamed into launching a more robust air campaign that facilitated a negotiated end to Bosnian War. ${ }^{23}$

Even ardent advocates of safe areas for the most part acknowledge that the Bosnian experiment failed abysmally. But the main lesson of Srebrenica, they argue, is not that safe areas are inherently problematic. Instead, safe areas can offer life-saving protection, provided that powerful countries, preferably the United States and its major allies, are fully committed to deterring potential assailants and repelling them if necessary-which the West shamefully failed to do in Bosnia. Supporters of the safe-area/safe zone approach often cite the safe zone established in 1991 to protect the Kurds of northern Iraq as a model to be followed. ${ }^{24}$

\section{Northern Iraq}

At the end of the 1991 Persian Gulf War, the Kurds of northern Iraq rose up against Saddam Hussein's oppressive rule. Yet troops loyal to the Iraqi dictator rapidly crushed the rebellion. That prompted hundreds of thousands of Kurdish civilians, who feared violent retaliation, to flee toward Turkey and Iran. After Turkey closed its border in early April 1991, over half a million Kurds became stranded under life-threatening conditions in the mountains along the Turkey-Iraq border. ${ }^{25}$ On 5 April, the UNSC adopted Resolution 688, which identified the cross-border refugee flows as a 'threat to international peace and security' and demanded that Iraq allow immediate access to humanitarian organisations. Three days later, British Prime Minister John Major proposed the establishment of 'safe enclaves' for the Kurds on Iraqi territory. The proposal was swiftly endorsed by other European governments. By mid-April, the United States also came to support the idea of carving out a protected area for

13January 2018. On the Bihac episode, see also Burg and Shoup, War in Bosnia-Herzegovina, pp. 154-59.

23 Ivo Daalder, Getting to Dayton: The Making of America's Bosnia Policy (Washington, DC: Brookings Institution Press, 2000), pp. 90-134; and Recchia, Reassuring the Reluctant Warriors, pp. ${ }^{128-} 35$.

24 See, for example, Schake, 'Safe Zones Proved Their Value after the Gulf War'; Robert DiPrizio, Armed Humanitarians: Us Interventions from Northern Iraq to Kosovo (Baltimore, MD: Johns Hopkins University Press, 2003), pp. 25-28; Seybolt, Humanitarian Military Intervention, pp. 191-94; and Orchard, 'Revisiting Humanitarian Safe Areas', pp. 6o-61.

25 McQueen, Safety Zones, p. 27; and David Romano, The Kurdish Nationalist Movement (Cambridge: Cambridge University Press, 2006), pp. 206-7. 
Iraq's Kurds and offered to lead a robust military operation to this end: the goal was to create a secure environment so that the Kurds could descend from the mountains and return to their places of origin. ${ }^{26}$

The us-led operation, code-named Operation Provide Comfort, comprised 21,00o troops at full deployment, with contributions from France, the United Kingdom, Italy, Spain, and the Netherlands. ${ }^{27}$ This credible international military presence persuaded the Iraqi government to pull back its forces as the us-led coalition advanced. Thomas Pickering, then the us representative to the United Nations, explains that 'we delivered several very tough messages through the UN channel and we got responses and we got action, in large measure because we had this huge preponderance of military force, and the Iraqis were not sure what we would do. ${ }^{28}$ However, President George H.W. Bush was unwilling to countenance a protracted us deployment, since his administration was under pressure from Congress to bring the troops home. ${ }^{29}$ By July 1991, with the immediate humanitarian crisis resolved, most us and allied troops left Iraq. The relief effort was handed off to UN civilian agencies and non-governmental organisations. For continued deterrence, the Western allies relied on a no-fly zone established over Iraq's northern skies (in addition, for a few months, they kept a 5,00o-strong rapid reaction force stationed across the border in Turkey)..$^{30}$

The northern Iraqi safe zone offered effective short-term protection and probably saved thousands of human lives. Circumstances at the time were favourable to the protection forces: Iraq had just suffered a crushing military defeat in the Persian Gulf War, making us and allied threats of punishing military action with respect to the Kurdish refugee issue uniquely credible. Nevertheless, over the medium term, Operation Provide Comfort appears to have had several problematic consequences that may actually have undermined civilian security in the region. In particular, there is evidence that the establishment of a

26 Jane E. Stromseth, 'Iraq's Repression of its Civilian Population: Collective Responses and Continuing Challenges' in Lori Fisler Damrosch (ed.), Enforcing Restraint: Collective Intervention in Internal Conflicts (New York: Council on Foreign Relations, 1993), pp. 89-9o; Sarah Graham-Brown, Sanctioning Saddam: The Politics of Intervention in Iraq (London: I.B. Tauris, 1999), pp. 26-28; and Wheeler, Saving Strangers, pp. 149-51.

27 John T. Fishel, Liberation, Occupation, and Rescue: War Termination and Desert Storm (Carlisle, PA: Us Army War College, 1992), p. 57; and DiPrizio, Armed Humanitarians, p. 26.

28 Author interview with Thomas Pickering, us Permanent Representative to the UN, 198992 (Washington, DC, 14 January 2011).

29 Graham-Brown, Sanctioning Saddam, pp. 37-39; and Wheeler, Saving Strangers, p. 157.

$30 \quad$ McQueen, Safety Zones, pp. 48-50; and Fishel, Liberation, Occupation, and Rescue, p. 57. 
safe zone by powerful states made the protected group - the Kurds of northern Iraq-less willing to compromise during political negotiations, more inclined to launch high-risk offensives, and more determined to pursue unilateral secession. The first two of these problematic consequences also occurred in Bosnia; hence, the two cases have more in common than is typically assumed.

\section{Problematic Outcome One: Reduced Incentives to Compromise}

Assuming that safe areas established by powerful states are adequately enforced, they can at best 'freeze' the underlying political conflict. As Richard Haas, a former senior us policymaker, notes, the purpose of safe areas is 'to keep people alive until the political situation changes, not to try to change the political situation directly, something that would prove too costly'. ${ }^{11}$ Ideally, safe areas can buy time, allowing diplomatic negotiations on a political settlement to proceed in the meantime. When the Srebrenica safe area in Bosnia was established in April 1993, for instance, it was seen as a short-term measure, to remain in place until the peace negotiations, which at the time seemed to be making good progress, culminated in a final settlement. ${ }^{32}$ However, if the negotiations stall and the war continues - which is precisely what happened in Bosnia - safe areas may have to remain in place indefinitely to protect civilian populations exposed to the threat of mass atrocities. This raises a dilemma known as the 'end-state problem': if the protection forces leave before a political solution is reached, they risk re-creating the same threatening conditions that prompted the international intervention..$^{33}$

In situations of ethnic civil war, safe areas established by powerful states typically offer protection to the members of one (or several) groups against the threat posed by other groups. What has not been sufficiently recognised to date is that when such safe areas encompass sizeable territories, they may complicate political negotiations and thus reduce the odds of a negotiated settlement. Assuming that the safe areas are adequately enforced, they will somewhat relieve the pressure on the protected groups, which are often the militarily weaker parties in the civil war; consequently, those groups are likely to view a political settlement as less urgent and may harden their stance at the

\footnotetext{
31 Richard Haass, 'Military Force: A User's Guide', Foreign Policy 96: 21-38 (1994), p. 26.

32 McQueen, Safety Zones, pp. 65-66.

33 Roland Paris, "The "Responsibility to Protect" and the Structural Problems of Preventive Humanitarian Intervention', International Peacekeeping 21/5: 569-603 (2014), p. 576.
} 
negotiating table. If fighting continues outside the safe areas and sometimes within them, while negotiations are drawn out for months or even years, civilian populations will suffer. In extreme cases, it might be that in the absence of protected safe areas and other forms of assistance to militarily weaker groups, these groups would sue for peace and accept a political settlement sooner in order to avoid complete battlefield defeat-potentially at a lesser overall cost in terms of civilian lives lost.

For instance, there is evidence that in Bosnia, once the UN had established the safe areas and NAто was seemingly committed to their protection, Alija Izetbegovic, the Bosnian Muslim leader, significantly hardened his stance in the peace negotiations. In August 1993, international mediators David Owen and Thorvald Stoltenberg presented a peace plan based on the principle of ethnic partition. The plan was conditionally accepted by the other parties; reportedly, however, the Bosnian Muslim side now had to be pressured even just 'to return to the talks after its hopes had been raised that NATO was preparing to intervene in Bosnia. ${ }^{34}$ The Muslims, who had faced a concrete risk of military defeat only months earlier, demanded significant additional territories beyond the thirty percent of the country awarded to them in the Owen-Stoltenberg proposal. When these demands were not met, Izetbegovic doomed the peace plan to failure by rejecting it in early September. ${ }^{35}$ Tens of thousands of civilians died as the war raged on for another two years, before a peace agreement was finally achieved at Dayton in late 1995 that partially reversed Serb territorial gains. ${ }^{36}$

Similarly, in northern Iraq in 1991, after the United States and its allies established the safe zone and pledged to protect the Kurdish population, Kurdish rebel forces became more ambitious in their political demands, seeking to extend their territorial control far beyond the protected enclave. The Kurds demanded that the cities of Kirkuk, Khaniqin, and Mandali (the latter two situated more than 100 miles outside the safe zone) be conceded to them. This contributed to the failure of political negotiations with Iraqi government authorities on a formal autonomy agreement for the Kurdish region, which the

\footnotetext{
34 Burg and Shoup, War in Bosnia-Herzegovina, p. 268.

35 Paul Lewis, 'At un, Bosnian Presses his Plea for More Land', New York Times, 8 September 1993. See also Burg and Shoup, War in Bosnia-Herzegovina, pp. 271-78.

36 According to the demographic unit of the International Criminal Tribunal for the Former Yugoslavia (ICTY), 104,732 people died from the war in Bosnia between 1992 and 1995. See Jan Zwierzchowski and Ewa Tabeau, 'The 1992-95 War in Bosnia-Herzegovina: Census-Based Multiple System Estimation of Casualties' Undercount', http://www.icty .org, accessed 13 January 2018.
} 
United States and its allies had strongly supported — not least because it could have reduced the need for outside protection. ${ }^{37}$

In the northern Iraq case, notwithstanding repeated provocations by Kurdish militias (discussed in more detail later), Iraqi government authorities did not resume large-scale hostilities against the Kurds. Iraq's government held back, even after the United States and its allies withdrew their ground forces, in large part because of the continued credible threat of international air strikes. But oppressive leaders elsewhere are unlikely to be as easily intimidated as Saddam Hussein was in the aftermath of his humbling defeat in the 1991 Gulf War. Furthermore, deterrence through air power may be altogether unfeasible in complex civil wars fought in densely populated areas. Absent a political compromise, one is left with the spectre of a return to large-scale atrocities against civilians as soon as the international protection forces withdraw.

\section{Problematic Outcome Two: High-risk Offensives Launched from Within the Safe Areas}

Ideally, once a safe area is established, robust military forces from powerful states will ensure its protection for as long as necessary, and militias inside the area will be disarmed. In practice, however, because of resource constraints and pressures from domestic audiences at home, powerful states are likely to be able to deploy their troops on civilian protection missions only for relatively short periods of time. Consequently, the international protectors can be expected to want to build up rather than dismantle the defensive capabilities of the protected, especially when no imminent peace settlement is in sight. At a minimum, the protectors are likely to resist disarming the protected, because they understand that such measures might make it very difficult for the international forces to leave.

The Srebrenica safe area, as noted, was initially proclaimed a demilitarised zone under UN auspices. But the United States subsequently pushed back against disarming the Bosnian Muslims in Srebrenica and in the other safe areas, sensing that this would leave the Muslims exceedingly vulnerable. ${ }^{38}$ After it became clear that the Western powers had no appetite for ensuring robust protection of the safe areas, the head of un peacekeeping, Kofi Annan, also stressed in a message to UN forces that they 'should not participate too actively in

\footnotetext{
37 David McDowall, A Modern History of the Kurds, revised ed. (London: I.B. Tauris, 2007), pp. 376-8. Romano (Kurdish Nationalist Movement, p. 208, n. 71) concludes that 'the allied offer of a safe haven made the negotiations' failure not too surprising'. 
"disarming the victims". ${ }^{39}$ Consequently, the idea of disarming the Bosnian safe areas was quietly shelved. In northern Iraq in 1991, disarming Kurdish militias inside the safe enclave was never among the international coalition's objectives; indeed, given that the United States wanted to withdraw its troops quickly, us forces ended up cooperating quite closely with the militias. ${ }^{40}$ Recent plans to establish safe areas in Syria, Libya, and Iraq likewise make no mention of demilitarisation. ${ }^{41}$

If a local group is allowed to maintain its own military forces within an internationally protected safe area, while hostilities continue elsewhere, there is a non-negligible possibility that the group will seek to exploit the safe area to advance its own military objectives. At the most basic level, safe areas allow militias from protected groups to recover from battle and reorganise. After they have had time to recover, the militias may use the safe areas as staging grounds for high-risk offensive operations, deliberately putting civilian lives at risk in the hope of drawing the protection forces more deeply into the war.

Such behaviour can be explained by the theory of 'moral hazard', according to which declarations and concrete steps taken by international actors to indicate that they are willing to protect a vulnerable party may encourage greater risk-taking by the latter. ${ }^{42}$ The 'moral hazard of humanitarian intervention' argument remains contested. In its strong form, the argument holds that when outside powers signal their willingness to protect vulnerable groups through military intervention, this 'unintentionally fosters rebellion' by encouraging armed factions from within these groups to initiate violence against other (stronger) groups. ${ }^{43}$ But, as Alex Bellamy and Paul Williams have shown, there is little evidence that expectations of humanitarian intervention cause sub-state groups to take up arms against stronger opponents. ${ }^{44}$ In its weaker form, the moral hazard argument holds that the prospect of humanitarian

39 Annan, 'Srebrenica'.

40 Graham-Brown, Sanctioning Saddam, pp. 29-30.

41 See, for example, Karen DeYoung, 'Kerry: Talks with Russia Seek to Separate Rival Forces in Syria with Safe Zones', Washington Post, 2 May 2016; ввс Monitoring Middle East, 'Algeria, Tunisia "Rejected Western Proposal for Safe Zone" in Libya'; and Soguel, 'A Sanctuary for Iraqi Yazidis'.

42 Dane Rowlands and David Carment, 'Moral Hazard and Conflict Intervention' in Murray Wolfson (ed.), The Political Economy of War and Peace (The Hague: Kluwer, 1998); Kuperman, 'The Moral Hazard of Humanitarian Intervention'; and Andrew H. Kydd and Scott Straus, 'The Road to Hell? Third-Party Intervention to Prevent Atrocities', American Journal of Political Science, 57/3: 673-84 (2013).

43 Kuperman, 'The Moral Hazard of Humanitarian Intervention', p. 51.

44 Alex J. Bellamy and Paul D. Williams, 'On the Limits of Moral Hazard: The "Responsibility to Protect”, Armed Conflict and Mass Atrocities', European Journal of International 
intervention may foster escalation (rather than initiation) of rebel violence. ${ }^{45}$ Anecdotal evidence, for instance from the Kosovo crisis in 1998-1999, supports this weaker form of the argument: from the fall of 1998 onward, sustained talk of humanitarian intervention by NATO in response to Serbia's repressive actions emboldened the Kosovo Liberation Army, the region's main rebel group, to step up its own military offensives against Serb security forces. ${ }^{46}$

To date, the moral hazard argument had not been applied to safe areas. Yet evidence from the northern Iraq and Bosnia safe areas supports the moral hazard argument in its weaker form. In both cases, the establishment of safe areas signalled that powerful states had committed themselves to protecting vulnerable parties. This encouraged these parties to behave more recklessly and, in particular, to launch high-risk military offensives aimed at drawing the protectors more deeply into the conflict.

In northern Iraq, after coalition forces had established the safe zone in the spring of 1991, Kurdish peshmerga militias stepped up their assaults on Iraqi army units, seeking a more decisive international intervention in support of an expanded area under Kurdish control and of ultimate Kurdish self-determination. ${ }^{47}$ Subsequently, as the Us-led coalition started to withdraw, coalition members issued stern warnings to Iraqi authorities that renewed oppression of the Kurds would result in crippling air strikes and possibly another ground intervention. These pronouncements, buttressed by the presence of the rapid reaction force over the border in Turkey, encouraged the Kurds to keep up their offensives. Peshmerga units continued to ambush Iraqi army detachments until well into the fall of 1991, reportedly hoping to trigger an Iraqi crackdown and thus 'to provoke' another international intervention. ${ }^{48}$ Kurdish militia

Relations, 18:3: 539-71 (2011), esp. pp. 546-48. See also Jon Western, 'Illusions of Moral Hazard: A Conceptual and Empirical Critique', Ethnopolitics, 4/2: 225-36 (2005).

45 Roberto Belloni, 'The Tragedy of Darfur and the Limits of the "Responsibility to Protect", Ethnopolitics, 5/4: 327-46 (2006); and Rowlands and Carment, 'Moral Hazard and Conflict Intervention'.

46 Wolfgang Petritsch, the European Union's envoy to Kosovo at the time, writes that the KLA's increased attacks from November 1998 onward were clearly intended to bring about Serb retaliation, with the goal of triggering a us-led military intervention. See Wolfgang Petritsch and Robert Pichler, Kosovo-Kosova: Der Lange Weg zum Frieden (Klagenfurt: Wieser, 2004), p. 148. See also David Gibbs, First Do No Harm: Humanitarian Intervention and the Destruction of Yugoslavia (Nashville, TN: Vanderbilt University Press, 2009), Ch. 7 .

47 Meir Litvak, 'Civil War in Iraq' in Ami Ayalon (ed.), Middle East Contemporary Survey, vol. 15 (Boulder, CO: Westview Press, 1991), p. 428; and Graham-Brown, Sanctioning Saddam, pp. 29-30.

48 McDowall, Modern History of the Kurds, p. 378. 
attacks resulted in renewed serious clashes between the militias and Iraqi government forces, with hundreds of civilians killed and tens of thousands forced to flee their homes, before intensified us sabre-rattling finally persuaded Iraq's government to completely withdraw its military forces from the region in late October. ${ }^{49}$

The Bosnian safe areas, with NATO seemingly committed to their protection, similarly emboldened the main protected group-the Bosnian Muslims. From early on, Muslim fighters took advantage of the safe areas to regroup and rest. ${ }^{50}$ Gradually, Muslim militias also began to use the safe areas as staging grounds for offensive operations, in spite of their military inferiority vis-à-vis the Bosnian Serbs, thus knowingly putting civilian populations inside the safe areas at risk. The Muslims' hope was that they would eventually persuade the United States and its allies to intervene more decisively on their behalf. ${ }^{51}$

In April 1994, Bosnian Muslim forces staged an attack out of the Gorazde safe area, and after a Serb a counteroffensive began to inflict heavy casualties on civilians inside the area, the Muslims succeeded for the first time in triggering limited NATO air strikes against Serb military installations. ${ }^{52}$ Likewise, in October 1994, Muslim forces launched an offensive out of the Bihac safe area, again triggering limited NAто air strikes when the safe area came under Serb shelling. ${ }^{53}$ Evidence made available through the International Criminal Tribunal for the Former Yugoslavia (ICTY) indicates that Srebrenica, too, was used as a jumping-off point for Muslim guerrilla activity in eastern Bosnia, before the safe area was taken by Serb forces in July $1995 .{ }^{54}$ The ensuing gruesome massacre of Muslim men in Srebrenica played a key role in triggering a more substantial NATO air campaign, Operation Deliberate Force, which significantly strengthened the Muslims' bargaining position during subsequent negotiations that

49 Graham-Brown, Sanctioning Saddam, p. 39; and McDowall, Modern History of the Kurds, p. 378 .

50 Landgren, 'Safety Zones and International Protection', p. 447; and McQueen, Safety Zones, p. 76 .

51 As Walter Slocome, who at the time was responsible for us policy coordination at the Pentagon recalls, 'the Bosniak [Bosnian Muslim] tactic of course was to induce the UN into the war'. Author interview (Washington, DC, 9 June 2011). See also Kuperman, 'The Moral Hazard of Humanitarian Intervention', p. 60.

$5^{2}$ McQueen, Safety Zones, pp. 77-78; and Burg and Shoup, War in Bosnia-Herzegovina, pp. $146-47$.

53 United Nations, 'Report on the fall of Srebrenica', pp. 38-39; and McQueen, Safety Zones, p. 79 .

54 ICTY, 'PROSECUTOR v. RADISLAV KRSTIC', Case No. IT-98-33-T (2 August 2001), pp. 8-9, http://www.icty.org/x/cases/krstic/tjug/en/krs-tjo10802e.pdf, accessed 13 January 2018. 
ended the war. ${ }^{55}$ There is a disturbing possibility that if powerful states had not signalled their willingness to intervene to protect the Bosnian safe areas, by the spring of 1993, the Muslims, far from launching further offensives, would have sued for peace. The war could thus have ended sooner-admittedly, at the cost of significant territorial losses for the Muslim side, but potentially at a lower cost in terms of civilian casualties. ${ }^{56}$

\section{Problematic Outcome Three: Inflamed Secessionist Passions}

When safe areas established by powerful states encompass sizeable territories inhabited by a particular ethnic group, and that group considers the territories to be part of its national homeland, this is likely to fuel secessionist sentiments. Some political philosophers argue that, in principle, we should 'let [any] encompassing group that forms a substantial majority in a territory have the right to determine whether that territory shall form an independent state. ${ }^{57}$ Others advocate a narrower right to secede, limited to groups that suffer serious human rights violations at the hands of the existing state. ${ }^{58}$ The available evidence, however, indicates that non-consensual secession and territorial partition, whether de facto or de jure, have more often than not 'fomented further violence and forced mass migration.59 In the absence of either massive population transfers to achieve ethnically homogeneous territories, or protracted (and costly) international stabilisation missions, non-consensual secession in fragile states is likely to undermine civilian security over the medium term. ${ }^{60}$

55 Daalder, Getting to Dayton, pp. 64-78; and Recchia, Reassuring the Reluctant Warriors, pp. ${ }^{128-30 .}$

56 In March 1993, Muslim leaders in Srebrenica had accepted Serb demands for surrender negotiations, before the UNSC changed the situation by declaring Srebrenica a safe area. See McQueen, Safety Zones, p. 58.

57 Avishai Margalit and Joseph Raz, 'National Self-Determination', Journal of Philosophy, 87/9: 439-62 (1990), p. 457 .

58 Allen Buchanan, Justice, Legitimacy, and Self-Determination (New York: Oxford University Press, 2003), Ch. 8.

59 Radha Kumar, 'The Troubled History of Partition', Foreign Affairs, 76/1: 22-34 (1997), p. 24. See also Bridget Coggins, 'The History of Secession' in Aleksandar Pavkovic and Peter Radan (eds.), The Ashgate Research Companion to Secession (Farnham: Ashgate, 2011), esp. pp. 32-37.

6o Even scholars sympathetic to ethnic partition acknowledge its destabilising implications over the medium term and emphasise that 'large-scale population transfers' are needed for it to yield longer-term stability. See Chaim Kaufmann, 'When All Else Fails: Ethnic Population Transfers and Partitions in the Twentieth Century', International Security, 23/2: $120-56$ (1998), p. 121. 
In Bosnia, the safe areas did not directly fuel secessionism, as the country's Muslims, whom the safe areas were primarily intended to protect, were committed to maintaining a unitary Bosnian state. By contrast, the northern Iraqi safe zone established in 1991 clearly inflamed secessionist passions: the safe zone encompassed large swathes of Iraqi Kurdistan; the Kurds had a longstanding desire to establish their own state; and they viewed the international intervention as their best chance yet to realise their political aspirations. Indeed, when the United States and its allies intervened to carve out a protected enclave in northern Iraq, they understood that this could fuel secessionist tendencies. ${ }^{61}$ Concerns about Iraq's territorial integrity among the broader UN membership also explain why, although UNSC Resolution 688 demanded that Iraq allow access to humanitarian organisations, the Security Council stopped short of explicitly authorising military intervention to assist the Kurds. ${ }^{62}$

The United States and its allies framed Operation Provide Comfort in northern Iraq as a purely humanitarian relief mission, seeking to allay international concerns at the UNSC and elsewhere that the safe zone might enable Kurdish secessionism. But once the us-led coalition had pledged to protect the Iraqi Kurds, it entered into a political dialogue with the Kurdish leadership aimed at streamlining the delivery of humanitarian assistance, thus legitimising that leadership. ${ }^{63}$ As noted, the establishment of the safe zone also emboldened Kurdish guerrilla fighters, until the Iraqi government, fearing us air strikes, decided to completely withdraw its forces from the region. That enabled Kurdish rebels to take control of an area roughly the size of Switzerland. In 1992, the Kurds then held elections for a Kurdish parliament and established their own government. Hence, within less than a year, the us-led intervention, notwithstanding its limited civilian protection objectives, had enabled the creation of the de facto state of Iraqi Kurdistan. ${ }^{64}$

Kosovo is another example of a large safe area set up by powerful states that fuelled secessionism. In the spring of 1999, after a 78-day NATO air campaign drove Serb security forces out of Kosovo, the Western alliance arguably 'creat[ed] a large safe zone that consisted of the entire province', with the goal of protecting the local ethnic Albanian population. ${ }^{65}$ In this case, the United States offered the secessionists its explicit political backing: before the launch

61 Graham-Brown, Sanctioning Saddam, pp. 25-27; Wheeler, Saving Strangers, p. 149; and DiPrizio, Armed Humanitarians, pp. 26, 29.

62 See McQueen, Safety Zones, pp. 35-36; and Wheeler, Saving Strangers, pp. 144-6.

63 Marianna Charountaki, The Kurds and U.s. Foreign Policy (London: Routledge, 2011), pp. ${ }^{168-70 .}$

64 Romano, Kurdish Nationalist Movement, p. 208; and Charountaki, Kurds and Us Foreign Policy, p. 171.

65 Seybolt, Humanitarian Intervention, p. 215. 
of NATO's air campaign, Secretary of State Madeleine Albright had promised the Kosovar Albanians in a secret letter that if they cooperated with Washington, they would soon be able to hold an internationally supervised referendum on independence. ${ }^{66}$

\section{Difficulties Handing Off Stabilisation to Multilateral Forces}

In Kosovo, after NATo had established a de facto safe area encompassing the entire province, the Western alliance was able to summon the political will to maintain a long-term military presence and thus to preserve political stability, in large part because of the region's strategic importance to Europe. ${ }^{67}$ However, if the United States and its allies intervened to establish large safe areas in strategically less important regions populated by militant secessionists, domestic pressures at home would make it difficult for the interveners to sustain the long-term military commitments that may well be needed to preserve stability and protect vulnerable civilians. ${ }^{68}$ In such circumstances, continued protection of civilians would probably depend on the interveners' ability to gradually hand off the stabilisation burden to more broadly based UN peacekeeping missions.

Such multilateral handoffs, however, are likely to be difficult when the initial military intervention that set up the safe area lacked authorisation and hence legitimation from the un Security Council. ${ }^{69}$ Indeed, China and Russia, with restive ethnic minorities of their own, are unlikely to offer any kind of support at the UNSC for non-consensual safe areas intended to protect groups with secessionist aspirations.

66 Uk Select Parliamentary Committee on Foreign Affairs, 'Kosovo: History of the Crisis', Memorandum by the Foreign and Commonwealth Office, 20 April 2000, para. 6o, www .publications.parliament.uk/pa/cm1999oo/cmselect/cmfaff/28/9111803.htm, accessed 13 January 2018. See also Tim Judah, Kosovo: War and Revenge, 2nd ed. (New Haven, Ст: Yale University Press, 2002), p. 215.

67 Kosovo achieved full (de jure) statehood in 2008 without further large-scale bloodshed. See Marc Weller, Contested Statehood: Kosovo's Struggle for Independence (Oxford: Oxford University Press, 2009), Ch. 11-12.

68 On how domestic pressures at home make it difficult for Western powers to sustain longterm humanitarian troop deployments, see James Lindsay, 'Congress and the Use of Force in the Post-Cold War Era' in The United States and the Use of Force in the Post-Cold War Era (Queenstown, MD: Aspen Institute, 1995); and William Howell and Jon Pevehouse, While Dangers Gather: Congressional Checks on Presidential War Powers (Princeton, NJ: Princeton University Press, 2007), Ch. 2.

69 On how advance UNSC approval for armed intervention increases the odds of longerterm international burden sharing, see Stefano Recchia, 'Authorising Humanitarian Intervention: A Five-Point Defence of Existing Multilateral Procedures', Review of International Studies, 43/1: 50-72 (2017), esp. pp. 66-68. 
In the 1991 northern Iraq crisis, once the United States and its allies had intervened, they sought the Security Council's backing for a UN peacekeeping force to maintain stability after the coalition's departure. But several other UNSC members, including China, viewed the original intervention that had established the safe zone as illegitimate, given its de facto support for a secessionist movement (as noted, the intervention had no explicit UN backing). Consequently, the UNSC was unwilling to support a follow-on UN peacekeeping mission in the area. ${ }^{70}$ Lack of a protracted international military presence to maintain stability in northern Iraq resulted in a vicious civil war between Kurdish factions from 1994 to 1998, which produced thousands of civilian casualties and tens of thousands of internally displaced. ${ }^{71}$ Likewise today, a hypothetical safe area established by the United States to protect the Syrian Kurds would be unlikely to secure UN backing. In the absence of a comprehensive peace agreement among the local parties, that would make subsequent international burden sharing to stabilise the safe area very difficult.

\section{Risk of Regional Spillovers}

Finally, when powerful states establish safe areas that wittingly or unwittingly advance the cause of militant secessionists, this may have destabilising regional spillover effects. Oppressed minorities elsewhere may be emboldened to take matters into their own hands, in the hope that they, too, will benefit from international assistance. The creation of a Kurdish de facto state in northern Iraq appears to have galvanised Kurdish armed groups in Turkey, producing a period of bloody conflict between the government in Ankara and its own Kurdish population between 1992 and 1995 that caused massive civilian suffering. ${ }^{72}$ Likewise, there is evidence that NATO's intervention in support of Kosovo's ethnic Albanian population and subsequent establishment of a large de facto safe area emboldened militant Albanian secessionists in nearby countries: in Macedonia between 2000 and 2001 the secessionists turned to violence, seeking to 'liberate' majority-Albanian parts of the country. Although casualty numbers remained relatively low in this case, thousands of civilians were forced to flee their homes. ${ }^{73}$

\footnotetext{
70 McQueen, Safety Zones, p. 49; and Wheeler, Saving Strangers, p. 156.

71 McDowall, Modern History of the Kurds, pp. 386-89; and Romano, Kurdish Nationalist Movement, pp. 209-10.

72 McDowall, Modern History of the Kurds, pp. 381-84; and Landgren, 'Safe Zones and International Protection', p. 443.

73 Peter H. Liotta, 'Spillover Effect: Aftershocks in Kosovo, Macedonia, and Serbia', Wilson Center Policy Brief No. 268, July 2011; and ввс News, 'Casualties in the Macedonian Conflict', 19 March 2001.
} 
TABLE 1 Problematic outcomes of safe areas established by powerful states

\begin{tabular}{lllll}
\hline & $\begin{array}{l}\text { Hardening of } \\
\text { negotiating stance }\end{array}$ & $\begin{array}{l}\text { Offensives staged } \\
\text { from protected area }\end{array}$ & $\begin{array}{l}\text { Secessionism } \\
\text { Regional } \\
\text { spillover }\end{array}$ \\
\hline Northern Iraq & Yes & Yes & Yes & Yes \\
Bosnia & Yes & Yes & No* & Yes* \\
Rwanda $^{*}$ & No & Yes & No & No \\
Kosovo $^{\text {a }}$ & Yes & No & Yes & Yes \\
\hline
\end{tabular}

*Serb secessionism in Bosnia was not directly fuelled by the safe areas, which aimed primarily at protecting Bosnian Muslim, rather than Serb, civilians. However, the Bosnian safe areas had regional spillover effects, inspiring Muslim Albanian insurgents in Kosovo.

${ }^{\times}$The Rwandan safe zone was established very late in the civil war and did not markedly influence the war's course. Nevertheless, extremist Hutu militia members operated within the zone, killing Tutsis.

${ }^{a}$ This de facto safe area, established after open hostilities ended, made the Kosovar Albanians less interested in a negotiated solution with Belgrade and boosted their aspirations toward national independence.

\section{Conclusion}

Activists and scholars calling on powerful states to intervene militarily to protect civilians from mass atrocities often invoke the Holocaust analogy. ${ }^{74}$ The Nazi Holocaust of the 1940 s is the paradigmatic case in which military intervention to protect innocent civilians was morally justified and perhaps required. However, in today's ethno-sectarian conflicts, most of the parties are typically armed and, to the extent that mass violence is inflicted upon civilians, the perpetrators often view it as a means to increase their bargaining leverage and extract concessions from the targeted group. ${ }^{75}$ In such contexts, outside intervention by powerful states - even if only for the purpose of establishing safe areas-can change the local balance of power and hence the political

74 Benjamin Valentino and Ethan Weinberg, 'More than Words? "Genocide," Holocaust Analogies, and Public Opinion in the United States', Journal of Human Rights, 16/3: 27692 (2017); and Aaron Magid, 'Evoking Holocaust, Lawmakers Demand "Never Again" for Syria', Jewish Journal, 22 March 2017.

75 See, for example, Alex de Waal, 'Violence and Peacemaking in the Political Marketplace', Accord, 25: 17-20 (April 2014). 
calculations of local groups, deterring atrocities in the short term but potentially increasing the risk of violence against civilians over the medium term.

Powerful states considering the establishment of safe areas for civilian protection purposes need to be aware of the potential downsides. In particular, as this article has suggested, they need to take seriously the possibility that internationally proclaimed safe areas encompassing large territories may undermine civilian protection over the medium term by (a) making protected groups less likely to compromise during peace negotiations; (b) encouraging protected groups to use the areas as staging grounds for high-risk military offensives; and (c) emboldening militant secessionist movements. What, then, can be done to minimise the likelihood of such adverse outcomes occurring?

If powerful states choose to intervene militarily with the goal of establishing safe areas, they should make it clear that they will not take sides in the local conflict. This is essential to avoid ambiguities that might otherwise be exploited by local parties. Safe areas should also preferably be limited to urban agglomeration areas, hospital zones, and camps for refugees and internally displaced persons, rather than encompassing entire provinces or regions, to minimise the likelihood that they will shift the balance of power in the civil war and to reduce the risk of unwittingly abetting militant secessionists. In addition, the interveners should make it clear to the protected group(s) from the outset that any attempts to exploit the safe areas for military advantage will be counterproductive: they will be condemned and potentially result in a scaling down of the international commitment. Finally, safe areas should ideally be fully demilitarised, in order to emphasise their civilian and non-political character, in line with the 1977 additional protocol to the fourth Geneva Convention. This, however, would require a strong international military commitment for as long as necessary, potentially for several years.

Prospective interveners need to be aware (and should explain to their domestic audiences) that establishing safe areas in complex ethnic wars is unlikely to be a low-cost means of civilian protection; instead, it may result in expensive commitments of indefinite duration. If powerful states are unwilling to shoulder such potentially long-term commitments for civilian protection purposes, it may be unwise for them to deploy their own troops to establish non-consensual safe areas to begin with-especially in the absence of broader multilateral buy-in.

When powerful outside actors decide not to deploy their troops on the ground to establish safe areas in situations where a risk of mass atrocities exists, they could still help relieve human suffering in various ways. First, at a minimum, they could support humanitarian relief organisations logistically and financially. Second, they could deploy their leverage-including through 
the imposition of economic sanctions and by conducting targeted air strikes, where feasible - with the goal of persuading the conflicting parties themselves to negotiate local cease-fires and proclaim consensual safe areas, as a first step towards a comprehensive cessation of hostilities. For instance, in 2017, Russia, Turkey, and Iran brokered a series of local cease-fires in Syria between the government and various rebel factions that resulted in the establishment of four limited safe zones, or 'de-escalation zones' (although these cease-fires remained exceedingly fragile in the absence of sustained pressure on the Syrian government). ${ }^{76}$

Safe areas established by consent among the local parties should not have to rely entirely on the parties' voluntary compliance for their success. Once an agreement has been achieved, international (preferably UN) forces could be deployed to monitor compliance and, if necessary, repel attacks by renegade factions. Alternatively, UN peacekeepers already deployed in civilian protection missions with the overall ('strategic') consent of the conflicting parties could proclaim limited safe areas out of their own initiative-for instance, around food distribution centres, hospital zones, and refugee camps. Such limited safe areas, established without the parties' 'tactical' consent, could facilitate the delivery of humanitarian assistance and provide temporary protection to vulnerable civilians. ${ }^{77}$ For example, in the Democratic Republic of the Congo (DRC), since 2003, UN forces have repeatedly established limited 'humanitarian buffer zones' and demilitarised 'security zones' for precisely these purposes. Likewise, in the Central African Republic (CAR), UN forces have established various 'weapons free zones' to protect civilians from armed groups. ${ }^{78}$

Safe areas policed by UN peacekeepers probably will not be able to offer the same level of short-term security that can be expected when powerful states

76 Frederik Pleitgen, 'Inside Syria's Safe Zones, Russia and Assad Hold the Cards', cNN, 7 August 2017, http://www.cnn.com/2017/08/07/middleeast/syria-safe-zones-russia/index .html, accessed 13 January 2018; and Nada Homsi and Anne Barnard, 'Marked for "De-escalation," Syrian Towns Endure Surge of Attacks', New York Times, 18 November 2017.

77 For the distinction between 'strategic' and 'tactical' consent in UN peacekeeping, see Und PKo, United Nations Peacekeeping Operations: Principles and Guidelines (New York, 2008), Ch. 2.

78 On the DRC, see McQueen, Safety Zones, p. 161; Un News Centre, 'Un Peacekeepers Set Up Buffer Zone in DR Congo to Facilitate Relief Aid Deliveries', 21 December 2004; and Jessica Hatcher, 'Un Gears Up for DRC offensive as Goma laments escalating violence', The Guardian, 8 August 2013. On the CAR, see 'UN Establishes "Weapons-Free Zone" in Central African Republic', Reuters, 9 September 2015; and Radio France Internationale, 'RCA: à Kaga-Bandoro, les armes n'ont pas complètement disparu', 2 February 2016. 
deploy their own troops in more ambitious operations under national command. However, on the upside, as long as safe areas and neutral zones policed by UN peacekeepers encompass only narrowly delimited territories and are prevented from becoming safe havens for armed groups, they are unlikely to change the political calculations of local parties in ways that may fuel the conflict and thereby worsen the plight of vulnerable civilians over the medium term. When it comes to protecting civilians from mass atrocities, less can sometimes be more. 